\title{
Failure of anti-hypertensive drugs to control blood pressure rise with isometric exercise in hypertension
}

\author{
J. A. O'HARE \\ M.B., M.R.C.P.I., M.R.C.P.(U.K.)
}

D. J. Murnaghan

B.Sc., M.B., F.R.C.P.I.

The Department of Medicine, Cork Regional Hospital and University College, Cork, Ireland

\begin{abstract}
Summary
Isometric exercise causes a substantial rise in BP in normotensive and untreated hypertensives. The authors studied the isometric hand-grip test in 5 groups of treated hypertensives, namely $\beta$-blockers, $\beta$-blockers + diuretics, $\beta$-blockers + diuretics + vasodilators, $\alpha$-methyldopa alone and labetalol. All groups showed a substantial rise in both systolic and diastolic BP, and the increments in BP differed little from that in normotensives. Some patients, despite multiple therapy, achieved increments of up to 60 mmHg from rest. Treated hypertensives with cardiac and cerebro-vascular disease are at risk performing isometric exercise.
\end{abstract}

\section{Introduction}

Isometric (static) exercise causes a substantial rise in systolic and diastolic BP in both normotensive and untreated hypertensive subjects (Hoel, Lorentsen and Lund-Larsen, 1970; Ewing et al., 1973). In patients with left ventricular impairment due to hypertension, coronary artery and other heart disease, isometric exercise can cause angina (Cohn et al., 1973), dangerously elevated left ventricular end-diastolic pressure (Cohn et al., 1973; Kivowitz et al., 1971; Helfant, de Villa and Meister, 1971), gallop rhythms (Fisher et al., 1975) and arrhythmias (Cohn et al., 1973). BP during isometric exercise can be extremely high in hypertensives, yet there are few studies on the effect of various anti-hypertensives in this area (Editorial, 1975).

In normotensives, $\beta$-blockers alone and $\alpha$ blockers (Martin et al., 1974), are ineffective. In hypertensives, prazosin and propranolol (Reuben, Gale and Blake 1979) used separately are ineffective in attenuating the BP rise in isometric exercise. The authors have studied the pulse and BP changes in 47 hypertensives to determine which of 5 different drug regimes attenuate the $\mathrm{BP}$ rise seen with isometric exercise.

\section{Patients and methods}

The isometric hand-grip test was used in a standardized manner after Ewing et al. (1974), using a mercury sphygmomanometer (Taylor, Belfied and Taylor, 1978). The subject squeezed the partiale inflated cuff at $30 \%$ of his maximum voluntas contraction until fatigue forced him to release hös grip. This took a mean of $3 \mathrm{~min}$ (range $2-5 \mathrm{~min}$ ). The pulse and BP (diastolic fifth phase) were mes sured on the non-exercising arm, before the test, at one-min intervals, and at the point of fatigue.

The 47 hypertensives, 32 male and 15 female, with a mean age of $43 \pm 16$ years were on treatment for at least 3 months. None of the patients was cardiac failure. Five treatment groups were studie group A $(n=9)$ patients on $\beta$-blockers alone, 7 we on propranolol and 2 on oxprenolol, mean sily dose $196 \pm 121 \mathrm{mg}$; group B $(n=17)$ patients $\beta$-blockers + diuretics, 14 were on propran बil, mean daily dose $200 \pm 96 \mathrm{mg}$, 9 were on thiazides and 5 on metolazone, 3 were on frusemide; group $(n=10)$ patients on $\beta$-blockers + diuretics vasodilators, 8 were on propranolol, mean dai dose $430 \pm 208 \mathrm{mg}, 4$ patients were on thiazides, $\stackrel{\mathcal{\Omega}}{\Omega}$ were on metolazone and 3 on frusemide, 5 patients were on hydrallazine, mean daily dose $160 \mathrm{mg}$, 3 were on diazoxide, mean $360 \mathrm{mg} /$ day and 2 were om prazosin, mean $15 \mathrm{mg} /$ day; group $\mathrm{D}(n=6)$ patients on $\alpha$-methyldopa, mean daily dose $1000 \mathrm{mg} /$ da group $\mathrm{E}(n=5)$ patients on labetalol, mean dai $\mathrm{B}$. dose $1100 \mathrm{mg} /$ day, 4 of these were also on thiazide diuretics.

Twenty-four medical personnel, 12 male and female, not on any medication acted as controk. Reasons for exclusion before admission to the study were: atrial fibrillation (because of difficulty measusing BP accurately) disability of the exercising limB and those with advanced renal failure (serum creatinine $>600 \mu \mathrm{mol} / \mathrm{l}$ ) as this impairs the $\mathrm{BP}$ response in the test (Ewing and Winny, 1975) The BP response with isometric exercise is greater males than in females (Freychus, 1970). A similap, though statistically not significant, trend in the controls was noted. Treatment groups were statistifo ally compared with the appropriate control grouf according to sex distribution, using unpaired Student's $t$ tests. 
TABLe 1. Control subjects, BP mean ( \pm s.d.) in $\mathrm{mmHg}$, and pulse, mean ( \pm s.d.) at rest and at fatigue after $30 \%$ maximum voluntary contraction

\begin{tabular}{lccccccccc}
\hline & \multicolumn{2}{c}{ Resting BP } & \multicolumn{2}{c}{ Fatigue BP } & \multicolumn{2}{c}{ Rise in BP } & \multicolumn{2}{c}{ Pulse } & \multicolumn{2}{c}{ Pulse } \\
No. of patients & Syst. & Diast. & Syst. & Diast. & Syst. & Diast. & Rest & Fatigue & rise \\
\hline Male (12) & 133 & 82 & 159 & 111 & 26 & 30 & 73 & 84 & 13 \\
& $(15)$ & $(10)$ & $(11)$ & $(13)$ & $(12)$ & $(15)$ & $(10)$ & $(10)$ & $(6)$ \\
Female (12) & 123 & 72 & 141 & 95 & 18 & 23 & 84 & 107 & 21 \\
& $(11)$ & $(7)$ & $(15)$ & $(13)$ & $(9)$ & $(8)$ & $(14)$ & $(23)$ & $(15)$ \\
M+F (24) & 128 & 77 & 150 & 103 & 22 & 27 & 79 & 103 & 19 \\
& $(14)$ & $(10)$ & $(16)$ & $(16)$ & $(12)$ & $(13)$ & $(13)$ & $(13)$ & $(13)$ \\
\hline
\end{tabular}

* Systolic BP rise $M>F,(t=1 \cdot 455), P=0.0796$.

$\dagger$ Diastolic BP rise $\mathrm{M}>\mathrm{F},(t=1 \cdot 282), P=0 \cdot 106$.

\section{Results}

Table 1 shows the BP and pulse changes in the control subjects-the changes were similar to previous reports in normotensive subjects (Martin et al., 1974; Ewing et al., 1974).

Figure 1 and Table 2 show the BP and pulse responses of the 5 treatment groups. There was a substantial rise in both systolic and diastolic BP in all groups. The incremental rise in systolic BP in the 5 treatment groups was $\geqslant$ than controls, i.e. there was no significant attenuation of systolic BP rise. A mild attenuation of the diastolic BP rise was obtained in groups B and D. Four hypertensives achieved systolic BP levels over $240 \mathrm{mmHg}, 9$ achieved diastolic BP levels of over $140 \mathrm{mmHg}$, and $4 \mathrm{had}$ an incremental rise of $60 \mathrm{mmHg}$ in the systolic BP from rest. The resting pulse rate in patients on $\beta$-blockers was lower than that in controls (reflecting compliance with therapy). The rise in pulse rate with isometric exercise was mildly

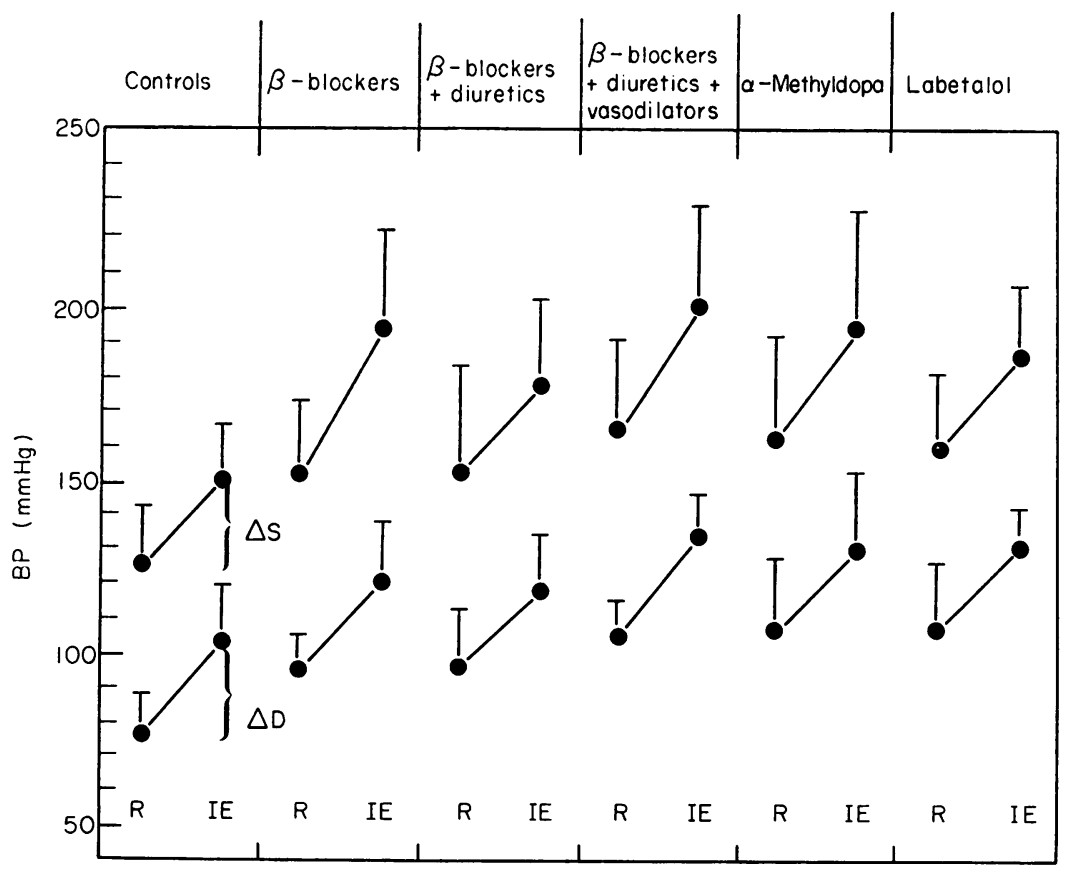

Fig. 1. Mean BP ( \pm s.d.) at rest and at fatigue point at $30 \%$ maximum voluntary contraction for controls (combined male and female) and 5 treatment groups.

$\triangle S=$ mean increment of systolic $B P$ and $\triangle D=$ mean increment of diastolic $B P . R=$ rest; IE $=$ isometric exercise. 
TABLE 2. Hypertensives: blood pressure in mmHg, mean ( \pm s.d.) and pulse mean ( \pm s.d.) changes from rest and fatigue at 30 儒 maximum voluntary contraction. Group A: $\beta$-blockers alone; Group B: $\beta$-blockers + diuretics; Group C: $\beta$-blockers + diuretic 8 + vasodilators; Group D: $\alpha$-methyldopa; Group E: labetalol.

\begin{tabular}{|c|c|c|c|c|c|c|c|c|c|c|c|c|c|c|}
\hline \multirow[b]{2}{*}{ Group } & \multicolumn{2}{|l|}{ Sex } & \multicolumn{2}{|c|}{ Resting BP } & \multicolumn{2}{|c|}{ Fatigue BP } & \multicolumn{2}{|c|}{ Rise in $\mathrm{BP}$} & \multicolumn{2}{|c|}{$\begin{array}{l}\text { Significance of } \\
\text { BP rise } v \text {. } \\
\text { controls: }\end{array}$} & \multicolumn{2}{|c|}{ Pulse } & \multirow{2}{*}{$\begin{array}{c}\text { Pulse } \\
\text { rise }\end{array}$} & \multirow{2}{*}{$\begin{array}{l}\text { Sig. pulse } \\
\text { rise from } \\
\text { controls: }\end{array}$} \\
\hline & $\mathbf{M}$ & $\mathbf{F}$ & Syst. & Diast. & Syst & Diast. & Syst, & Diast. & Syst. & Diast. I & Rest & Fatigue & & \\
\hline$A^{*}$ & 6 & 3 & $\begin{array}{l}153 \\
(18)\end{array}$ & $\begin{array}{l}96 \\
(9)\end{array}$ & $\begin{array}{l}195 \\
(26)\end{array}$ & $\begin{array}{r}122 \\
(15)\end{array}$ & $\begin{array}{c}42 \\
(12)\end{array}$ & $\begin{array}{c}28 \\
(10)\end{array}$ & NS & NS & $\begin{array}{l}65 \\
(9)\end{array}$ & $\begin{array}{l}78 \\
(8)\end{array}$ & $\begin{array}{l}11 \\
(9)\end{array}$ & NS \\
\hline $\mathrm{B} \dagger$ & 9 & 8 & $\begin{array}{l}154 \\
(27)\end{array}$ & $\begin{array}{c}97 \\
(14)\end{array}$ & $\begin{array}{l}178 \\
(24)\end{array}$ & $\begin{array}{l}117 \\
(15)\end{array}$ & $\begin{array}{c}24 \\
(16)\end{array}$ & $\begin{array}{l}20 \\
(9)\end{array}$ & NS & $P<0.05$ & $\begin{array}{l}65 \\
(8)\end{array}$ & $\begin{array}{c}75 \\
(12)\end{array}$ & $\begin{array}{l}10 \\
(8)\end{array}$ & $P<0.01$ \\
\hline$C^{*}$ & 10 & 0 & $\begin{array}{l}166 \\
(24)\end{array}$ & $\begin{array}{l}106 \\
(8)\end{array}$ & $\begin{array}{l}199 \\
(30)\end{array}$ & $\begin{array}{l}134 \\
(11)\end{array}$ & $\begin{array}{c}35 \\
(13)\end{array}$ & $\begin{array}{c}28 \\
(11)\end{array}$ & NS & NS & $\begin{array}{l}67 \\
(7)\end{array}$ & $\begin{array}{c}80 \\
(13)\end{array}$ & $\begin{array}{l}13 \\
(9)\end{array}$ & NS \\
\hline D* & 5 & 1 & $\begin{array}{l}162 \\
(30)\end{array}$ & $\begin{array}{l}109 \\
(19)\end{array}$ & $\begin{array}{l}193 \\
(34)\end{array}$ & $\begin{array}{l}130 \\
(23)\end{array}$ & $\begin{array}{c}28 \\
(11)\end{array}$ & $\begin{array}{c}18 \\
(16)\end{array}$ & NS & $P<0.02$ & $\begin{array}{c}82 \\
(15)\end{array}$ & $\begin{array}{l}104 \\
(19)\end{array}$ & $\begin{array}{c}22 \\
(10)\end{array}$ & NS \\
\hline $\mathrm{E} \dagger$ & 3 & 2 & $\begin{array}{l}159 \\
(21)\end{array}$ & $\begin{array}{l}108 \\
(18)\end{array}$ & $\begin{array}{l}184 \\
(22)\end{array}$ & $\begin{array}{l}130 \\
(11)\end{array}$ & $\begin{array}{c}25 \\
(14)\end{array}$ & $\begin{array}{c}22 \\
(11)\end{array}$ & NS & NS & $\begin{array}{c}76 \\
(11)\end{array}$ & $\begin{array}{l}93 \\
(9)\end{array}$ & $\begin{array}{c}18 \\
(17)\end{array}$ & NS \\
\hline
\end{tabular}

attenuated in all patients on $\beta$-blockers $(P<0.01$ in group $B)$. None of the patients suffered clinically apparent adverse effects during the tests.

\section{Discussion}

The authors have demonstrated the failure of some of the most commonly used anti-hypertensive drugs in therapeutic doses, both alone and in combination, appreciably to attenuate the substantial rise in BP seen in isometric exercise. The magnitude of the BP rise in normotensives and hypertensives has previously been shown to be similar, but hypertensives achieve higher absolute BP levels, (Hoel et al., 1970; Ewing et al., 1973). A systolic BP $>240 \mathrm{mmHg}$ or a diastolic BP $>140 \mathrm{mmHg}$ was recorded in 12 patients, despite treatment with multiple drug therapy sufficient to attain reasonable steady state BP levels.

The mechanism of the BP rise in untreated subjects is well understood. For the BP rise to be significant, the subject must exercise at greater than $20 \%$ of the maximum voluntary contraction of the muscle group used and, as fatigue develops, the BP rises steadily (Lind et al., 1964). In normotensive and hypertensive subjects without left ventricular impairment, the BP rise is due to increased cardiac output (Martin et al., 1974), initially by withdrawal of vagal tone and, as fatigue develops, by cardiac sympathetic drive; peripheral resistance usually remains unchanged. However, if the subject has left ventricular impairment (Ewing et al., 1973), or is on $\beta$-blockers (Martin et al., 1974), the BP rise is mainly by increased peripheral resistance mediated by $\alpha$-adrenergic receptors (Martin et al., 1974). Thus, it is possible to interpret the action of various anti-hypertensives in isometric exercise.
Previous studies have been with single drug therapy only. Beta-blockers (Reuben et al., 1979g Taylor, Belfield and Taylor, 1978) as well as blockers (Freychus, 1970; Reuben et al., 1979), are ineffective in attenuating BP rise. In their patientQ the present authors also demonstrated the ofneffectiveness of $\beta$-blockers alone. They there studied the effects ofadditional therapy with diure which, besides causing a natriuresis, probably also have a direct effect on the arteriolar wall reducin peripheral resistance (Jones and Nanra, 1979). The result was a modest $(P<0.05)$ attenuation of the diastolic rise in BP only, compared to controls However, when vasodilators were combined wit diuretics and $\beta$-blockers (group $C$ ) the expected further attenuation of the BP rise was not seen Indeed, the systolic and diastolic BP increments with exercise were greater than those in group B, although similar to those in controls. These findings could not. be explained by inadequate drug dosage as the meap daily dose of propranolol $(450 \mathrm{mg})$ was higher than in groups $\mathbf{A}$ and $\mathbf{B}$, and the diuretics and vaso? dilators were used in standard or maximum doses. Patients on $\alpha$-methyldopa showed no systolic and $\mathrm{a}$ mild diastolic attenuation of BP response. The latter is surprising as $\alpha$-methyldopa is not though to act on the peripheral autonomic nervous systerfy where the links in this reflex could be acted on. However, $\alpha$-methyldopa could diminish periphera resistance through damping of the central sympathes tic mechanisms (Nickerson and Riedy, 1975). The failure of labetalol, which has both $\alpha$ - and $\beta$ blocking properties during dynamic exercise (Fagarg et al., 1979), should theoretically block the 2 major pathways which mediate the BP rise to isometric exercise. The mean daily dose was $1100 \mathrm{mg}$ whic 
corresponds to an average therapeutic dose, and one patient who was on $2400 \mathrm{mg} /$ day still had a rise in BP similar to that in controls. The heart rate rise on labetalol was 18 beats/min, confirming the findings in a recent study (Balasubramanian et al., 1979), which showed that labetalol does not give complete $\beta$-blockade at normal doses. However, none of the drugs, including $\beta$-blockers, can prevent the initial rise in pulse that is mediated by vagal withdrawal, which increases cardiac output and thus allows some BP escape. Furthermore, it would seem that vasodilators, which reduce steady state peripheral resistance, cannot sufficiently attenuate the sudden and severe demands of the sympathetic nervous system in isometric exercise.

Besides the cardiovascular hazards outlined earlier, isometric exercise has been associated with subarachnoid haemorrhage (Lynch, 1980), and may increase the risk of other cerebro-vascular accidents, both during isometric exercise and in the long-term, by increasing the daily time-averaged arterial pressure (Ewing et al., 1973). Thus, the authors advise patients to avoid unnecessary isometric exercise in work and recreation. Alternatively, they advise patients to re-distribute loads to larger muscle groups (Ewing et al., 1975), e.g. carrying a load on the back rather than by hand, as strain is less and fatigue reached more slowly, thereby avoiding substantial rises in BP.

\section{References}

Balasubramanian, V., Mann, S., Millar-Craig, M.W. \& RAFTERY, E.B. (1979) Effect of labetalol in hypertension and during exercise and postural changes. British Journal of Clinical Pharmacology, 8, 95S.

Cohn, P.F., Thompson, P., Strauss, W., Todd, J. \& Gorlin, T. (1973) Diastolic heart sounds during static handgrip exercise in patients with chest pain. Circulation, 47, 1217.

EDITORIAL (1975) Let me carry your suitcase. Lancet, ii, 754.

EwING, D.J., Irving, J.B., KerR, F. \& KIRBY, B.J. (1973) Static exercise in untreated hypertension. British Heart Journal, 35, 413.

Ewing, D.J., Irving, J.B., KerR, F. \& Muir, A.L. (1975) Weight-carrying after myocardial infarction. Lancet, $\mathbf{i}$, 1113.

EWING, D.J., Irving, J.B., KerR, F., Wildsmith, J.A.W. \& Clarke, (1974) Cardiovascular responses to sustained handgrip in normal subjects and in patients with diabetes mellitus. A test of autonomic function. Clinical Science and Molecular Medicine, 46, 295.

EwING, D.J. \& WINNY, R. (1975) Autonomic function in patients with chronic renal failure on haemodialysis. Nephron, 15, 424.

Fagard, R., Antoon, A., Reybrouk, T., Lijnen, P. \& BILliET, L. (1979) Response of the systemic and pulmonary circulation to alpha- and beta-receptor blockade (labetalol) at rest and during exercise in hypertensive patients. Circulation, 60, 1214.

Fisher, M.L., NutTer, D.O., Jacobs, W. \& Schlant, R.C. (1975). Haemodynamic responses to isometric (handgrip) in patients with heart disease. British Heart Journal, 35, 422.

Freychus, U. (1970) Elicitation of heart rate and blood pressure increase on muscular contraction. Journal of Applied Physiology, 28, 758.

Helfant, R.H., DE Villa, M.A. \& Meister, S.G. (1971) Effect of sustained isometric handgrip on left ventricular performance. Circulation, 44, 982.

Hoel, B.L., Lorensten, E. \& Lund-Larsen, P.G. (1970) Haemodynamic responses to sustained handgrip in patients with hypertension. Acta medica scandinavica, 188, 491.

JoNES, B. \& NANRA, R.S. (1979) Double-blind trial of antihypertensive effect of chlorthiazide in severe renal failure. Lancet, ii, 1258.

Kivowitz, C., Parmley, W.W., Donooso, R., Marcus, H., GaNZ, W. \& SWAN, H.J.C. (1971) Effects of isometric exercise on cardiac performance - The handgrip test. Circulation, 44, 994.

Lind, A.R., TAYlor, S.H., Humphreys, P.W., Kennelly, B.M. \& Donald, K.W. (1964) Circulatory effects of sustained voluntary muscle contraction. Clinical Science, 27, 229.

LYNCH, P. (1980) Soldiers, sport, and sudden death. Lancet, i, 1235.

Martin, C.E., Shaver, A.J., Leon, D.F., Thompson, M.E., REDDY, P.S. \& LeONARD, J.J. (1974) Autonomic mechanisms in haemodynamic response in isometric exercise. Journal of Clinical Investigation, 54, 104.

Nickerson, M. \& RiEDY, J. (1975) Anti-hypertensive agents and the drug therapy of hypertension. In: The Pharmacological Basis of Therapeutics. (Ed by Goodman, L.S. \& Gilman, A.) 5th edn, p. 705. MacMillan Publishing Co., New York.

Reuben, S.R., Gale, E.U. \& Blake, P. (1979) The effect of alpha- and beta-adrenergic receptor blockers on the pressure responses to isometric exercise in hypertensive patients. British Journal of Clinical Pharmacology, 8, 365.

TAYlor, J.A., Belfield, P.W. \& TAYlOR, S.H. (1978) Effects of metoprolol on pressor responses to exercise and cold. In: Modern Aspects of Beta-Blocker Therapy. (Ed by Birdwood, G.F.B. \& Wink, C.A.S.), p. 85. Geigy Pharmaceuticals, Macclesfield. 